\section{FAKTOR PEYEBAB TERJADINYA DIRECT DAN INDIRECT WASTE PADA PROYEK BANGUNAN BERTINGKAT DI SURABAYA}

\author{
Michella Beatrix ${ }^{1, *)}$ \\ ${ }^{1}$ Universitas 17 Agustus 1945 Surabaya, \\ michella@untag-sby.ac.id
}

\section{ABSTRAK}

Pada proyek konstruksi terjadinya waste merupakan hal yang mungkin saja akan terus terjadi. Waste yang terjadi dapat berskala besar maupun kecil tergantung dari faktor penyebabnya dan dampaknya, dan hal ini memberikan pengaruh dalam pelaksanaan khususnya bagi pihak kontraktor sebagai penyedia jasa. Banyak hal yang dapat menjadi faktor terjadinya waste, dan hal ini pun tidak dapat dihindari. Pada Proyek konstruksi bangunan bertingkat di Surabaya terjadinya waste juga sering terjadi dan dipengaruhi oleh beberap faktor. Oleh karena itu Penelitian ini menitik beratkan pada faktor yang menyebabkan terjadinya waste konstruksi (direct dan inderet waste) pada proyek bangunan bertingkat di Surabaya. Penelitian ini menggunakan penyebaran data berupa kuisioner kepada pihak kontraktor di Surabaya dengan batasan kualifikasi perusahaan adalah perusahaan kontraktor menengah hingga besar. Pengolahan data kuisioner yang telah diperoleh diolah menggunakan Analisa Regresi Berganda. Hasil penelitian ini adalah 3 faktor yang memiliki pengaruh terbesar peyebab terjadinya waste yaitu faktor penaganan, Faktor Lain-lain, dan Faktor Pengadaan. Adapun besarnya faktor - faktor tersebut berdasarkan hasil penelitian adalah faktor penanganan sebesar 35\%, faktor lain-lain sebesar $23 \%$ dan faktor pengadaan $17 \%$.
Kata Kunci : Waste Konstruksi, Direct Waste, Indirect Waste, Faktor Penyebab Waste

\section{ABSTRACT}

In construction projects, the occurrence of waste is something that will probably continue to happen. Waste that occurs can be large or small depending on the factors causing it and its impact, and this affects the implementation, especially for the contractor as a service provider. Many things can be a factor in the occurrence of waste, and cannot avoid. In the construction project of building in Surabaya, the occurrence of waste also often occurs and is influenced by several factors. Therefore this research focuses on the factors that cause construction waste (direct and serial waste) in projects of building in Surabaya. This study uses data distribution in the form of questionnaires to contractors in Surabaya with the limitation of company qualifications being medium to large contractor companies. Processing the questionnaire data that has been obtained using Multiple Regression Analysis. The results of this study are 3 factors that have the greatest influence on the occurrence of waste, namely the factor of handling, Other Factors, and Procurement Factors. The magnitude of these factors based on the research results is a handling factor of $35 \%$, other factors at 23\%, and a procurement factor of $17 \%$.

Keywords: Construction Waste, Direct Waste, Indirect Waste, Factors Causing Waste

\section{PENDAHULUAN}

Dalam pekerjaan konstruksi, dituntut adanya suatu perencanaan yang baik dan tepat di setiap aspek agar tidak terjadi berbagai hal yang dapat menghambat berjalannya pekerjaan konstruksi tersebut, baik dalam aspek perencanaan hingga 
sampai dengan aspek pelaksanaan konstruksi. Sumber daya material yang merupakan salah satu sumber daya terpenting dalam proses pelaksanaan pekerjaan konstruksi, hal ini dikarenakan material dalam proyek konstruksi rentan memberikan pengaruh terhadap biaya.

Material bahan konstruksi yang tidak direncanakan dengan baik akan menimbulkan pemborosan material dalam proyek konstruksi sehingga memberikan dampak yang sangat besar berupa besarnya pengeluaran biaya proyek untuk pembangunan, selain itu juga dapat menyebabkan efek signifikan pada estetika, kesehatan, dan lingkungan umum, yang mana hal ini menyebabkan adanya Waste atau material Waste konstruksi yang tidak terpakai. Menurut Jailoon dkk (2009), Waste yang timbul didalam proyek memiliki kaitan terhadap metode pelaksanaan kegiatan konstruksi, yaitu proses memilah dan menggunakan kembali fasilitas dari Waste konstruksi dalam pelaksanaan proyek, serta tingkat pendidikan dan keahlian para pekerja.

Bagi pelaku konstruksi terutama bagi penyedia jasa konstruksi dalam hal ini kontraktor, apabila Waste yang dihasilkan memiliki jumlah atau porsi yang besar dari yang diperkirakan, akan berdampak memberikan kerugian bagi perusahaan. Kerugian tidak hanya berupa fisik namun juga dapat berupa nonfisik seperti banyaknya waktu yang terbuang akibat banyaknya masalah yang timbul oleh adanya Waste.

Waste yang terindikasi didalam lapangan proyek dapat disebabkan oleh beberapa penyebab. Gavilan \& Bernold (1994), mengkategorikan ke dalam sumbersumber yang dapat menjadi penyebab terjadinya Waste konstruksi menjadi enam kategori: (1) disain; (2) pengadaan material; (3) penanganan material; (4) pelaksanaan; (5) residual dan (6) lain-lain. Hasil penelitian Bossink dan Browers (1996).
Waste digolongkan menjadi dua bagian (Tchobanoglous, Theisen, \& Vigil, 1993) yaitu:

1. Demolition Waste adalah Waste yang dapat muncul dikarenakan adanya hasil pekerjaan pembongkaran, renovasi atau penghancuran gedung lama.

2. Construction Waste adalah adanya Waste konstruksi yang berasal dari proses pembangunan atau renovasi bangunan. Sisa material atau waste konstruksi tersebut tidak dapat dipakai lagi sesuai dengan fungsi semula. Sisa material ini bisa terdiri dari sisa bahan beton, sisa material batu bata, sisa plesteran, sisa material kayu, pipa dan lain-lain.

Construction Waste digolongkan menjadi dua tipe (Skoyles, 1976) yaitu:

1. Direct Waste adalah timbulnya Waste proyek yang disebabkan oleh adanya material bahan yang telah rusak, hilang dan sudah tidak dapat digunakan lagi.

2. Indirect Waste adalah Waste yang terjadi di proyek dikarenakan adanya volume pemakaian melebihi dari yang telah direncanakan, sehingga tidak terjadi Waste secara fisik di lapangan akan tetapi memberikan pengaruh serta dampak terhadap biaya secara tersembunyi (hidden cost), misalnya pekerjaan plesteran, yaitu ketebalan melebihi ketebalan/volume yang ditentukan / direncanakan dikarenakan adanya terjadi deviasi dimensi elemen struktur pada saat pengecoran.

Menurut penelitian Suryanto, Alifen, \& Lie (2005) Sumber-sumber dan faktor penyebab utama yang mempengaruhi sisa material di lapangan adalah:

1. Residu yaitu

Adanya sisa pemotongan/ kelebihan material pada akhir/ selesai pekerjaan

2. Pelaksanaan

Tidak ada perencanaan pemotongan material sebelum pelaksanaan. Munculnya kesalahan/ kecerobohan pekerja di lapangan. Deviasi elemen 
struktur menyebabkan pemakaian material berlebih.

3. Penanganan material

Kecerobohan pada saat penanganan material di lapangan. Ketidaktelitian pada saat menerima dan memeriksa material dari suplier. Rusak/patah pada saat proses dipindahkan. Tercecer pada saat diangkut.

Berdasarkan kategori dari sisa material, prosentase pada direct Waste lebih besar dari prosentase pada indirect Waste, kecuali terhadap material bahan konstruksi pasir dan batu pecah dimana sebagian besar sisa material yang terjadi akan mempengaruhi biaya secara tersembunyi (hidden cost), sehingga kurang memberikan pengaruh terhadap lingkungan.

Oleh sebab itu penelitian ini berfokus pada faktor penyebab timbulnya Waste, dimana Waste dalam penelitian ini dibagi menjadi dua yaitu direct Waste dan indirect Waste. Penelitian ini bertujuan untuk menentukan faktor-faktor apa sajakah yang berpengaruh menyebabkan terjadinya waste, beserta besarnya pengaruh terhadap terjadinya waste.

\section{METODE PENELITIAN}

Penelitian ini dilakukan dengan proses penyebaran kuisioner. Penyebaran kuisioner ditujukan kepada para penyedia jasa konstruksi dalam hal ini adalah pihak Kontraktor. Pihak Kotraktor yang dipilih dalam penelitian ini adalah yang memiliki kualifikasi perusahaan Menengah dan Besar yang pernah atau sedang mengerjakan proyek konstruksi bangunan bertingkat di Surabaya selama 5 tahun terakhir. Para responden dalam penelitian ini adalah yang memiliki jabatan Project Manager hingga pelaksana atau yang berkaitan dengan pengawasan material.

Kuisioner dalam penelitian ini menggunakan Skala Linkert dimana masing-masing indikator dari faktor tersebut akan dijabarkan dalam beberapa pernyataan kemudian dapat memberikan penilaian sesuai skala yang telah diberikan yaitu dengan skala sebagai berikut ini:

Skala $1=$ Sangat tidak setuju

Skala $2=$ Tidak Setuju

Skala 3 = Cukup Setuju

Skala $4=$ Setuju

Skala $5=$ Sangat Setuju

Setelah kuisioner terkumpul maka akan dilakukan analisa data dengan menggunakan uji statistic Analisa Regresi Berganda. Adapun Alir penelitian ini dapat dijelaskan dalam bagan alir penelitian berikut ini.

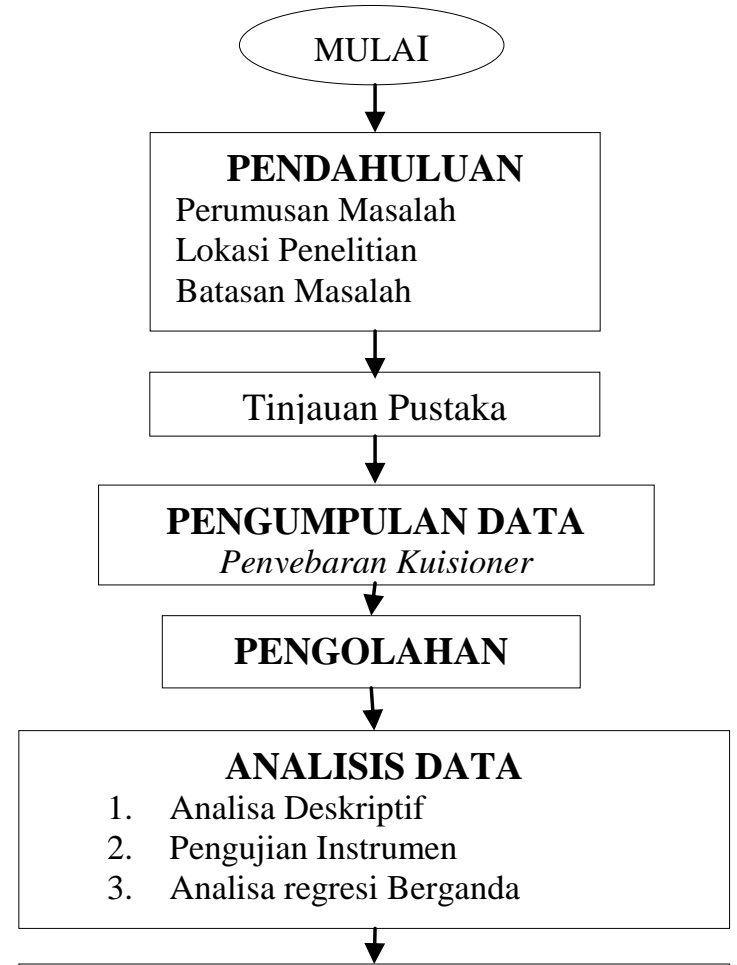

ANALISIS DAN PEMBAHASAN

1. Faktor Penyebab Direct Waste dan Indirect Waste

2. Besarnya pengaruh faktor penyebab.

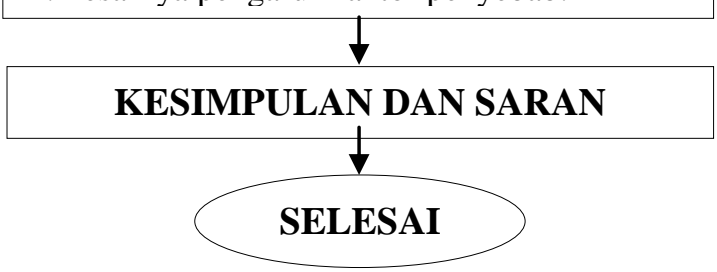

Gambar 1.

Flowchart Penelitian 
Analisa data dalam penelitian ini dilakukan dalam 3 tahap yaitu analisa deskriptif, pengujian instrumen dan analisa regresi berganda. Data faktor penyebab dalam penelitian ini dibagi menjadi 6 faktor yaitu faktor desain, pengadaan, penanganan, pelaksanaan, residual, dan lain-lain yang disajikan pada tabel 1 . dibawah ini.

Tabel 1.

Indikator Faktor-faktor Penyebab

\begin{tabular}{|c|c|c|}
\hline \multicolumn{3}{|c|}{ INDIKATOR } \\
\hline \multirow{11}{*}{$\begin{array}{l}\text { Faktor } \\
\text { Desain }\end{array}$} & $\mathrm{X} 1.1$ & $\begin{array}{l}\text { Kesalahan pada draft } \\
\text { dokumen kontrak }\end{array}$ \\
\hline & $\mathrm{X} 1.2$ & $\begin{array}{l}\text { Ketidak lengkapan } \\
\text { pada data draft } \\
\text { dokumen kontrak }\end{array}$ \\
\hline & $\mathrm{X} 1.3$ & $\begin{array}{l}\text { Terjadinya Perubahan } \\
\text { desain }\end{array}$ \\
\hline & $\mathrm{X} 1.4$ & $\begin{array}{l}\text { Pemilihan spesifikasi } \\
\text { produk }\end{array}$ \\
\hline & $\mathrm{X} 1.5$ & $\begin{array}{l}\text { Pemilihan produk } \\
\text { dengan kualitas } \\
\text { rendah }\end{array}$ \\
\hline & $\mathrm{X} 1.6$ & $\begin{array}{l}\text { Kurangnya perhatian } \\
\text { terhadap ukuran } \\
\text { produk yang dipakai }\end{array}$ \\
\hline & $\mathrm{X} 1.7$ & $\begin{array}{l}\text { Perencana tidak } \\
\text { paham jenis bahan } \\
\text { produk lain }\end{array}$ \\
\hline & X1.8 & $\begin{array}{l}\text { Gambar detail terlalu } \\
\text { rumit }\end{array}$ \\
\hline & $\mathrm{X} 1.9$ & $\begin{array}{l}\text { Kurangnya informasi } \\
\text { didalam gambar }\end{array}$ \\
\hline & $\mathrm{X} 1.10$ & $\begin{array}{l}\text { Koordinasi yang } \\
\text { kurang dengan } \\
\text { kontraktor dan }\end{array}$ \\
\hline & $\mathrm{X} 1.11$ & $\begin{array}{l}\text { Kurangnya } \\
\text { Pengalaman } \\
\text { Mengenai Konstruksi }\end{array}$ \\
\hline \multirow{3}{*}{$\begin{array}{l}\text { Faktor } \\
\text { Pengadaan }\end{array}$} & $\mathrm{X} 2.1$ & $\begin{array}{l}\text { Kesalahan terjadi pada } \\
\text { saat pemesanan, } \\
\text { kelebihan, } \\
\text { kekurangan, dsb. }\end{array}$ \\
\hline & $\mathrm{X} 2.2$ & $\begin{array}{l}\text { Pesanan yang harus } \\
\text { dalam jumlah yang } \\
\text { besar }\end{array}$ \\
\hline & $\mathrm{X} 2.3$ & $\begin{array}{l}\text { Pembelian material } \\
\text { tidak sesuai dengan } \\
\text { spesifikasi yang }\end{array}$ \\
\hline
\end{tabular}

\begin{tabular}{|c|c|c|}
\hline & & direncanakan \\
\hline & $\mathrm{X} 2.4$ & $\begin{array}{l}\text { Pengiriman barang } \\
\text { yang tidak sesuai } \\
\text { spesifikasi yang } \\
\text { diberikan oleh } \\
\text { pemasok }\end{array}$ \\
\hline & $\mathrm{X} 2.5$ & $\begin{array}{l}\text { Pengemasan yang } \\
\text { kurang baik sehingga } \\
\text { terjadi kerusakan } \\
\text { selama diperjalanan }\end{array}$ \\
\hline \multirow{6}{*}{$\begin{array}{c}\text { Faktor } \\
\text { Penanganan }\end{array}$} & X3.1 & $\begin{array}{l}\text { Material tidak di } \\
\text { kemas dengan baik } \\
\text { dan benar }\end{array}$ \\
\hline & $\mathrm{X} 3.2$ & $\begin{array}{l}\text { Material yang dikirim } \\
\text { dalam keadaan tidak } \\
\text { padat / kurang padat }\end{array}$ \\
\hline & $\mathrm{X} 3.3$ & $\begin{array}{l}\text { Membuang / } \\
\text { melempar material }\end{array}$ \\
\hline & X3.4 & $\begin{array}{l}\text { Penanganan material } \\
\text { yang tidak } \\
\text { dilaksanakan dengan } \\
\text { hati-hati pada saat } \\
\text { proses pembongkaran }\end{array}$ \\
\hline & $\mathrm{X} 3.5$ & $\begin{array}{l}\text { Penyimpanan bahan } \\
\text { material yang tidak / } \\
\text { kurang benar sehingga } \\
\text { menyebabkan } \\
\text { terjadinya kerusakan }\end{array}$ \\
\hline & X3.6 & $\begin{array}{l}\text { Rusaknya material } \\
\text { akibat transportasi } \\
\text { ke/di lokasi proyek }\end{array}$ \\
\hline \multirow{7}{*}{$\begin{array}{c}\text { Faktor } \\
\text { Pelaksanaan }\end{array}$} & $\mathrm{X} 4.1$ & $\begin{array}{l}\text { Kesalahan yang } \\
\text { muncul diakibatkan } \\
\text { oleh tenaga kerja }\end{array}$ \\
\hline & $\mathrm{X} 4.2$ & $\begin{array}{l}\text { Peralatan yang tidak } \\
\text { dapat berfungsi } \\
\text { dengan sangat baik }\end{array}$ \\
\hline & $\mathrm{X} 4.3$ & Cuaca buruk \\
\hline & $\mathrm{X} 4.4$ & $\begin{array}{l}\text { Kecelakaan pada } \\
\text { pekerja yang terjadi di } \\
\text { lapangan }\end{array}$ \\
\hline & $\mathrm{X} 4.5$ & $\begin{array}{l}\text { Penggunaan bahan } \\
\text { material yang salah } \\
\text { sehingga perlu adanya } \\
\text { pergantian }\end{array}$ \\
\hline & $\mathrm{X} 4.6$ & $\begin{array}{l}\text { Metode untuk } \\
\text { penempatan pondasi }\end{array}$ \\
\hline & $\mathrm{X} 4.7$ & $\begin{array}{l}\text { Jumlah material yang } \\
\text { diperlukan tidak } \\
\text { diketahui dikarenakan } \\
\text { perencanaan yang } \\
\text { tidak baik }\end{array}$ \\
\hline
\end{tabular}




\begin{tabular}{|c|c|c|}
\hline & $\mathrm{X} 4.8$ & $\begin{array}{l}\text { Informasi jenis dan } \\
\text { ukuran bahan material } \\
\text { yang akan digunakan } \\
\text { terlambat } \\
\text { tersampaikan kepada } \\
\text { kontraktor }\end{array}$ \\
\hline & $\mathrm{X} 4.9$ & $\begin{array}{l}\text { Kecerobohan dalam } \\
\text { pencampuran, } \\
\text { pengolahan dan } \\
\text { kesalahan dalam } \\
\text { penggunaan material } \\
\text { sehingga perlu ada } \\
\text { pergantian. }\end{array}$ \\
\hline & $\mathrm{X} 4.10$ & $\begin{array}{l}\text { Pengukuran di } \\
\text { lapangan tidak } \\
\text { presisi/akurat } \\
\text { sehingga terjadi } \\
\text { adanya kelebihan } \\
\text { volume }\end{array}$ \\
\hline \multirow{5}{*}{$\begin{array}{l}\text { Faktor } \\
\text { Residual }\end{array}$} & X5.1 & $\begin{array}{l}\text { Sisa potongan } \\
\text { material yang tidak } \\
\text { dapat digunakan lagi }\end{array}$ \\
\hline & $\mathrm{X} 5.2$ & $\begin{array}{l}\text { Kesalahan pada saat } \\
\text { memotong material }\end{array}$ \\
\hline & $\mathrm{X} 5.3$ & $\begin{array}{l}\text { Kesalahan pada saat } \\
\text { memesan barang, } \\
\text { karena tidak } \\
\text { menguasai spesifikasi }\end{array}$ \\
\hline & $\mathrm{X} 5.4$ & Proses pengemasan \\
\hline & X5.5 & $\begin{array}{l}\text { Sisa material yang } \\
\text { muncul karena } \\
\text { pemakaian }\end{array}$ \\
\hline \multirow[b]{2}{*}{$\begin{array}{l}\text { Faktor Lain- } \\
\text { Lain }\end{array}$} & X6.1 & $\begin{array}{l}\text { Kehilangan akibat } \\
\text { pencurian }\end{array}$ \\
\hline & X6.2 & $\begin{array}{l}\text { Buruknya kontrol } \\
\text { bahan material di } \\
\text { proyek dan } \\
\text { perencanaan } \\
\text { manajemen terhadap } \\
\text { sisa bahan material }\end{array}$ \\
\hline
\end{tabular}

Sumber : Bossink \& Brouwers, (1996) ; Alwi, S., Hampson, K. and Mohamed, S. (2002); Ekanayake L.L. and Ofori, G. (2000); Formoso, C.T., Lucio Soibelman, M., De Cesare, C. and Isatto, E.L. (2002); Kulatunga, U., Amaratunga, D. Haigh, R. and Rameezden, R. (2006).

\section{HASIL DAN PEMBAHASAN}

Kuisioner yang telah disebarkan, yang diperoleh peneliti adalah berjumlah 76 kuisioner, kuisioner yang diperoleh akan disaring dan diolah kedalam analisa deskriptif, pengujian instrument dan analisa regresi berganda untuk menjawab rumusan masalah dalam penelitian ini. Adapun analisa data dalam penelitian ini adalah sebagai berikut.

\subsection{ANALISA DESKRIPTIF}

Analisa deskriptif dalam penelitian ini adalah analisa deskriptif responden yang dibagi menjadi 2 kategori yaitu mengenai karakteristik responden dan karakteristik perusahaan. Analisa karakteristik responden pada penelitian ini dibagi menjadi 2 (dua) hal yaitu berdasarkan pengalaman bekerja di dunia konstruksi dan Jabatan saat kuisioner disebarkan. Berdasarkan 76 kuisioner yang diperoleh, maka dapat dijabarkan analisanya sebagai berikut.

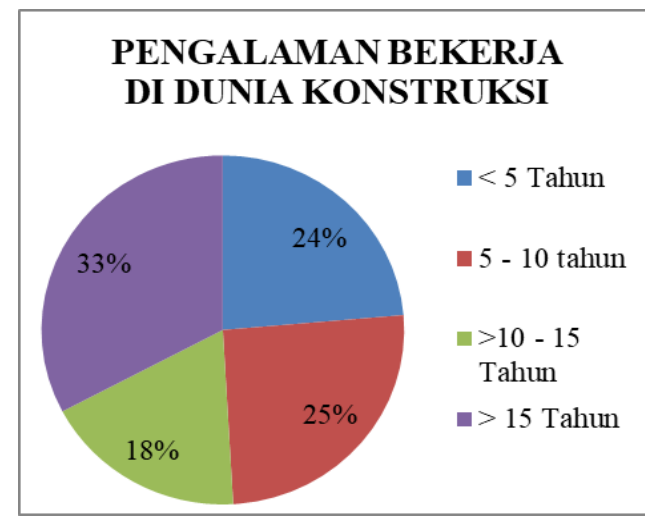

Gambar 2.

Deskripsi Pengalaman Bekerja di Dunia Konstruksi

(Hasil Olahan Peneliti, 2020)

Berdasarkan pengalaman bekerja didunia konstruksi para responden sebagian besar telah berpengalaman $>15$ tahun (33\%), 5-10 tahun dengan prosentase 25\%, $<5$ tahun $24 \%$, dan $>10-15$ tahun dengan prosentase $(18 \%)$. Berdasarkan jabatannya, kuisioner lebih banyak diisi oleh responden yang memiliki jabatan sebagai Project Manager, $18 \%$ dijawab oleh responden dengana jabatan others, dalam hal ini sebagai kepala logistik, Asisten direktur, 
asisten pelaksana, dsbnya. $17 \%$ responden berjabatan pelaksana, $12 \%$ dengan jabatan responden sebagai site engineering, dan $8 \%$ Site Manager.

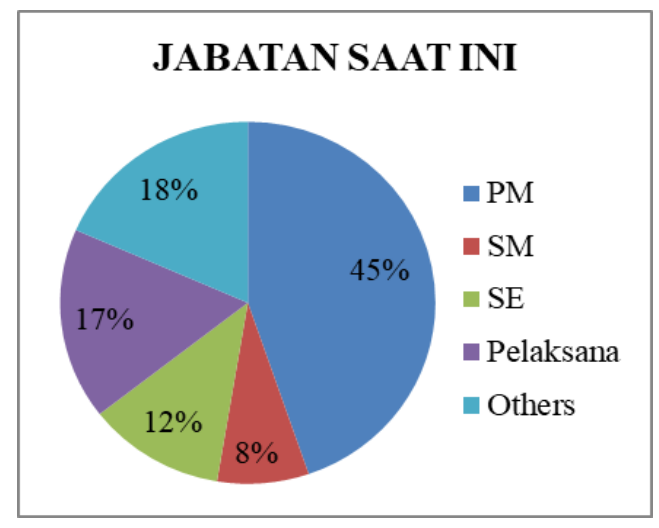

Gambar 3.

Deskripsi Jabatan Respomden (Hasil Olahan Peneliti, 2020)

Karakteristik perusahaan responden meliputi kualifikasi perusahaan dan kepemilikan perusahaan. Kualifikasi perusahaan dibagi menjadi tiga yaitu kualifikasi kecil, menengah dan besar. Sedangkan untuk kepemilikan perusahaan dibagi menjadi 3 bagian yaitu BUMN, Swasta Nasional, dan Swasta asing.

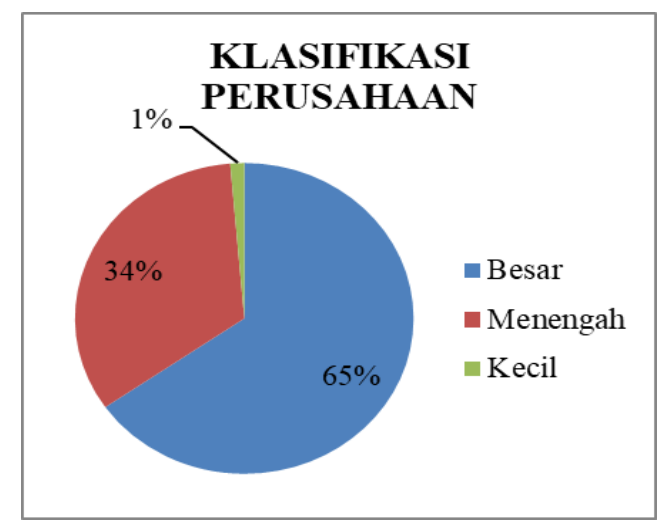

Gambar 4.

Deskripsi Kualifikasi Perusahaan

(Hasil Olahan Peneliti, 2020)

Deskripsi kualifikasi perusahaan dibagi menjadi 3 kategori yaitu besar, menengah, dan kecil. Hasil identifikasi yang ditunjukkan pada Gambar 4. diperoleh bahwa sebagian besar perusahaan responden masuk dalam kategori kualifikasi perusahaan besar hal ini ditunjukkan dengan jumlah prosentase sebesar $65 \%$. Sedangkan sisanya sebesar $34 \%$ kualifikasi menengah, dan $1 \%$ kualifikasi kecil, sehingga untuk kuisioner yang digunakan adalah dengan kulifikasi perusahaan responden dengan skala besar dan menengah.

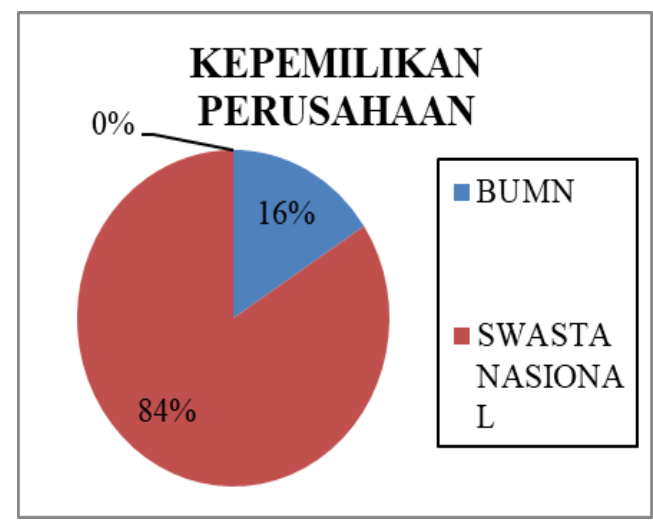

Gambar 5.

Deskripsi Kepemilikan Perusahaan (Hasil Olahan Peneliti, 2020)

Deskripsi kualifikasi perusahaan digunakan untuk memastikan bahwa penyebaran kuisioner telah memenuhi salah satu batasan penelitian ini. Salah satu batasan dalam penelitian ini diantaranya perusahaan kontraktor yang dituju adalah kualifikasi perusahaan kontraktor menengah hingga besar. Terkait kepemilikan perusaahan rata-rata perusahaan responden adalah perusahaan swasta nasional dengan prosentase $84 \%$, dan sisanya $16 \%$ adalah BUMN.

Dari 76 kuisioner, yang dapat diolah setelah melalui proses penyaringan berupa kualifikasi perusahaan, dan pernah tidaknya mengerjakan proyek bangunan bertingkat di Surabaya selama 5 tahun terahir, maka diperoleh data kuisioner yang dapat diolah sebanyak 70 kuisioner. Selanjutnya 70 kuisioner tersebut diuji ke tahap analisa selanjunya yaitu analisa pengujian instrumen. 


\subsection{PENGUJIAN INSTRUMEN}

Sehubungan penelitian ini menggunakan uji Analisa Regresi Berganda dan Analisa Faktor, maka untuk pengujina instrument akan menggunakan 2 data masing-masing pengujian, yaitu data pengujian untuk Variabel $\mathrm{X}$ dan $\mathrm{Y}$ terhadap kuisioner hasil jawaban 70 responden.

\subsubsection{UJI VALIDITAS}

Uji Validitas berguna untuk melihat kelayakan dari item-item pertanyaan dalam kuesioner ini dan uji validitas ini dilakukan pada setiap item pertanyaan didalam kuesioner. Dalam penelitian ini digunakan 54 item pertanyaan yang akan diuji validitasnya. Dalam uji validitas dalam penelitian ini t tabel bernilai 0.235. Menentukan valid atau tidaknya variabel dilakukan dengan melihat nilai $\mathrm{t}$ hitung $>\mathrm{t}$ tabel , maka variabel dinyatakan valid.

Setelah di lakukan pengujian hingga 4 kali pengujian maka diperoleh data valid yang ditujukan dala tabel 2. Berikut ini.

Tabel 2.

Hasil Uji Validitas IV

\begin{tabular}{|l|l|l|l|}
\hline $\mathbf{X 1 . 3}$ & 0.279 & 0.235 & Valid \\
\hline $\mathbf{X 1 . 4}$ & 0.349 & 0.235 & Valid \\
\hline $\mathbf{X 1 . 6}$ & 0.551 & 0.235 & Valid \\
\hline $\mathbf{X 1 . 7}$ & 0.695 & 0.235 & Valid \\
\hline $\mathbf{X 1 . 8}$ & 0.593 & 0.235 & Valid \\
\hline $\mathbf{X 1 . 9}$ & 0.621 & 0.235 & Valid \\
\hline $\mathbf{X 1 . 1 0}$ & 0.624 & 0.235 & Valid \\
\hline $\mathbf{X 1 . 1 1}$ & 0.677 & 0.235 & Valid \\
\hline $\mathbf{X 2 . 1}$ & 0.694 & 0.235 & Valid \\
\hline $\mathbf{X 2 . 2}$ & 0.589 & 0.235 & Valid \\
\hline $\mathbf{X 2 . 3}$ & 0.645 & 0.235 & Valid \\
\hline $\mathbf{X 2 . 4}$ & 0.679 & 0.235 & Valid \\
\hline $\mathbf{X 2 . 5}$ & 0.607 & 0.235 & Valid \\
\hline $\mathbf{X 3 . 1}$ & 0.599 & 0.235 & Valid \\
\hline $\mathbf{X 3 . 2}$ & 0.625 & 0.235 & Valid \\
\hline $\mathbf{X 3 . 3}$ & 0.629 & 0.235 & Valid \\
\hline $\mathbf{X 3 . 4}$ & 0.572 & 0.235 & Valid \\
\hline
\end{tabular}

\begin{tabular}{|c|c|c|c|}
\hline X3.5 & 0.648 & 0.235 & Valid \\
\hline X3.6 & 0.651 & 0.235 & Valid \\
\hline X4.1 & 0.754 & 0.235 & Valid \\
\hline X4.2 & 0.690 & 0.235 & Valid \\
\hline X4.3 & 0.553 & 0.235 & Valid \\
\hline X4.4 & 0.565 & 0.235 & Valid \\
\hline X4.5 & 0.706 & 0.235 & Valid \\
\hline X4.6 & 0.402 & 0.235 & Valid \\
\hline X4.7 & 0.710 & 0.235 & Valid \\
\hline X4.8 & 0.766 & 0.235 & Valid \\
\hline X4.9 & 0.744 & 0.235 & Valid \\
\hline X4.10 & 0.752 & 0.235 & Valid \\
\hline X5.1 & 0.439 & 0.235 & Valid \\
\hline X5.2 & 0.756 & 0.235 & Valid \\
\hline X5.3 & 0.697 & 0.235 & Valid \\
\hline X5.4 & 0.422 & 0.235 & Valid \\
\hline X5.5 & 0.606 & 0.235 & Valid \\
\hline X6.1 & 0.603 & 0.235 & Valid \\
\hline X6.2 & 0.644 & 0.235 & Valid \\
\hline Y1.5 & 0.282 & 0.235 & Valid \\
\hline Y1.9 & 0.379 & 0.235 & Valid \\
\hline Y1.12 & 0.270 & 0.235 & Valid \\
\hline Y1.15 & 0.408 & 0.235 & Valid \\
\hline Sumber & Hald \\
\hline
\end{tabular}

Sumber : Hasil Olahan Peneliti, (2020)

Dari uji validitas diatas, terdapat 40 item pertanyaan Variabel $\mathrm{X}$ dan $\mathrm{Y}$ yang dinyatakan valid dari 54 item pertanyaan, sehingga untuk analisa statistik dapat dilajutkan ke dalam penelitian selanjutnya.

\subsubsection{UJI REALIBILITAS}

Dalam pengujian reabilitas ini digunakan metode Cronbach's Alpha dengan aplikasi SPSS V.26. Pada uji ini bila nilai koefisien yang diperoleh lebih dari 0,6 maka instrumen dinyatakan reliabel. Bisa dilihat hasil pengujian reabilitas yang ada pada tabel dibawah ini : 
Tabel 3.

Reliability Statistics

\begin{tabular}{|r|r|}
\hline $\begin{array}{c}\text { Cronbach's } \\
\text { Alpha }\end{array}$ & N of Items \\
\hline .973 & 40 \\
\hline
\end{tabular}

Sumber : Hasil Olahan Peneliti menggunakan SPSS.v.26, (2020)

Berdasarkan Tabel 3. Diperoleh nilai Cronbach's Alpha adalah 0,973 lebih besar dari 0,6 , maka instrumen dinyatakan reliabel dan dapat dilanjutkan ke tahap selanjutnya yaitu Analisa Regresi Berganda.

\subsection{ANALISA REGRESI BERGANDA}

Analisa regresi linier berganda digunakan untuk melihat besarnya pengaruh penyebab terjadinya Waste yang dilambangkan sebagai variabel $X$ pada kuesioner, Desain (X1), Penanganan (X2), Pengadaan (X3), Pelaksanaan (X4), Residual (X5), Lain-lain terhadap Material Waste (Y) pada proyek Konstruksi Bangunan Bertingkat di Surabaya, dari hasil data yang telah dikumpulkan dengan menggunakan aplikasi SPSS v26.

Untuk uji F, Hipotesis untuk penelitian ini adalah:

- H0 = tidak adanya pengaruh dari variabel - variabel bebas (X1 - X6) terhadap variabel terikat $(\mathrm{Y})$

- $\mathrm{H} 1=$ adanya pengaruh dari variabel variabel bebas $(\mathrm{X} 1-\mathrm{X} 6)$ terhadap variabel terikat $(\mathrm{Y})$

Tabel 4.

Hasil analisis Uji F

\begin{tabular}{|c|c|c|c|c|c|c|}
\hline \multicolumn{7}{|c|}{ ANOVA $^{a}$} \\
\hline Model & & Sum of Squares & $d f$ & Mean Square & $\mathrm{F}$ & Sig. \\
\hline \multirow[t]{3}{*}{1} & Regression & 185.480 & 6 & 30.913 & 6.492 & $.000^{\circ}$ \\
\hline & Residual & 300.005 & 63 & 4.762 & & \\
\hline & Total & 485.486 & 69 & & & \\
\hline
\end{tabular}

a. Dependent Variable: $Y$

b. Predictors: (Constant), X6, X1, X3, X2, X5, X4

Sumber : Hasil Olahan Peneliti menggunakan SPSS.v.26, (2020)
Berdasarkan dari nilai tabel 4. yang didapat, analisis regresi yang dilakukan adalah signifikan dimana nilai $\mathrm{F}$ hitung $(6,492)>\mathrm{F}$ tabel $(2,25)$ sehingga peryataan H0 ditolak sementara H1 diterima. Variabel-variabel bebas mempunyai pengaruh yang signifikan terhadap variabel terikat.

Uji T merupakan pengujian yang digunakan untuk menguji signifikan konstanta dan variabel bebas secara parsial. Uji $\mathrm{T}$ dalam penelitian ini adalah sebagai berikut.

Tabel 5.

Hasil analisis Uji T

\begin{tabular}{|c|c|c|c|c|c|c|}
\hline \multicolumn{7}{|c|}{ Coefficients $^{a}$} \\
\hline & & \multirow{2}{*}{\multicolumn{2}{|c|}{ Unstandardized Coefficients }} & \multirow{3}{*}{$\begin{array}{c}\text { Standardized } \\
\text { Coefficients } \\
\text { Beta } \\
\end{array}$} & \multirow[b]{3}{*}{$t$} & \multirow[b]{3}{*}{ Sig. } \\
\hline & & & & & & \\
\hline \multicolumn{2}{|l|}{ Model } & $B$ & Std. Error & & & \\
\hline \multirow[t]{7}{*}{1} & (Constant) & 8.808 & 1.315 & & 6.697 & .000 \\
\hline & $\mathrm{X} 1$ & .059 & .083 & .161 & .715 & .477 \\
\hline & $\mathrm{x} 2$ & .168 & .117 & .330 & 1.429 & .158 \\
\hline & $\mathrm{X} 3$ & -198 & .069 & -.555 & -2.860 & .006 \\
\hline & $\mathrm{x}_{4}$ & .059 & .076 & .247 & .776 & .440 \\
\hline & $\times 5$ & -.071 & .141 & -.129 & -.508 & .614 \\
\hline & $\mathrm{X}_{6}$ & .447 & .238 & .394 & 1.881 & .065 \\
\hline
\end{tabular}

Sumber : Hasil Olahan Peneliti menggunakan SPSS.v.26, (2020)

Dengan menggunakan data dari $\mathrm{t}$ hitung pada uji T. Dari Tabel 5 dapat diketahui bahwa nilai $t$ hitung terbesar dimiliki oleh variabel Faktor Penanganan yaitu sebesar 2.86. untuk mengetahui prosentase variabel dominan terhadap variabel keseluruhan maka dapat dilakukan dengan rumus sebagai berikut ditunjukan pada tabel 4.

Tabel 6.

Prosentase Faktor

\begin{tabular}{|c|l|c|c|}
\hline No & \multicolumn{1}{|c|}{ Faktor } & $\begin{array}{c}\text { Nilai } \\
\text { Uji T }\end{array}$ & $\begin{array}{c}\text { Prosentase } \\
(\mathbf{\%})\end{array}$ \\
\hline 1 & Desain (X1) & 0.715 & 8.753 \\
\hline 2 & Pengadaan (X2) & 1.429 & 17.493 \\
\hline 3 & $\begin{array}{l}\text { Penanganan } \\
\text { (X3) }\end{array}$ & 2.86 & 35.010 \\
\hline 4 & $\begin{array}{l}\text { Pelaksanaan } \\
\text { (X4) }\end{array}$ & 0.776 & 9.499 \\
\hline 5 & Residual (X5) & 0.508 & 6.219 \\
\hline
\end{tabular}




\begin{tabular}{|c|c|c|c|}
\hline No & Faktor & $\begin{array}{c}\text { Nilai } \\
\text { Uji T }\end{array}$ & $\begin{array}{c}\text { Prosentase } \\
(\boldsymbol{\%})\end{array}$ \\
\hline 6 & Lain-Lain (X6) & 1.881 & 23.026 \\
\hline & Total & $\mathbf{8 . 1 6 9}$ & $\mathbf{1 0 0}$ \\
\hline
\end{tabular}

Sumber : Hasil Olahan Peneliti (2020)

Berdasarkan tabel 6 diatas maka berikut ini adalah gambaran diagram prosentase faktor variabel dominan terhadap variabel keseluruhan.

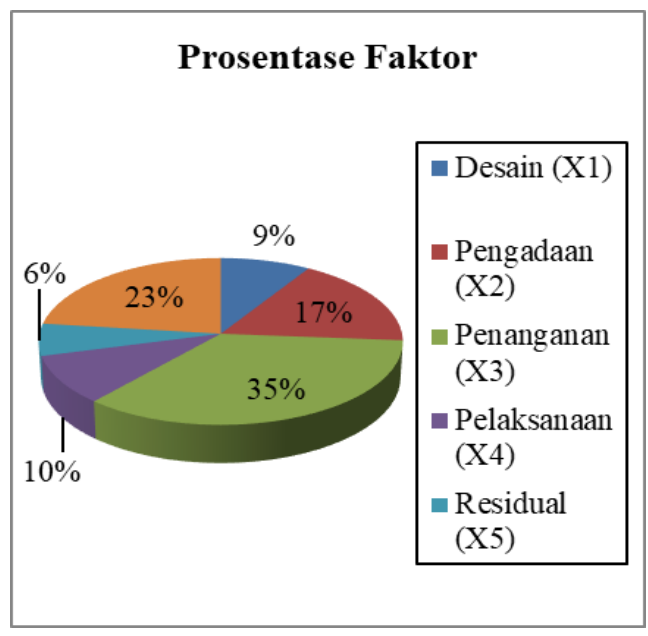

Gambar 6.

Diagram Prosentase Faktor

Sumber : Hasil Olahan Peneliti (2020)

Berdasarkan hasil perhitungan dan gambaran diagram prosentase faktor variabel dominan terhadap variabel keseluruhan, maka ke 6 variabel tersebut memiliki pengaruh terhadap terjadinya Waste Construction (Direct dan Indirect Waste) Pada Proyek Bangunan Bertingkat di Surabaya. Namun, dari 6 variabel tersebut diperoleh 3 faktor yang memiliki pengaruh terbesar yaitu Faktor Penanganan, Faktor Lain-Lain, dan Faktor Pengadaan. Besarnya nilai prosentase pengaruh dari faktor penanganan yang telah dihitung yaitu sebesar $35 \%$, Faktor Lain-lain 23\%, dan Faktor Pengadaan $17 \%$.

Adapun pengaruh terbesar dalam penelitian ini adalah Faktor penanganan, dimana faktor penanganan ini dapat berupa material tidak di kemas dengan baik dan benar, material yang dikirim dalam keadaan tidak padat/kurang, membuang/melempar material, penanganan material yang tidak dilakukan secara hati-hati pada saat pembongkaran, penyimpanan material yang tidak benar menyebabkan kerusakan, bahkan Kerusakan material akibat transportasi ke/di lokasi proyek.

Sedangkan untuk pengaruh terbesar kedua adalah faktor lain-lain yang terdiri dari kehilangan akibat pencurian, buruknya pengontrolan material di proyek dan perencanaan manajemen terhadap sisa material,

Pengaruh Terbesar ketiga terjadinya waste adalah faktor pengadaan, dimana faktor pengadaan ini dapat berupa kesalahan dalam pemesanan, kelebihan, kekurangan, dsb. Pesanan yang harus dalam jumlah yang besar, pembelian material tidak sesuai dengan spesifikasi rencana, pengiriman barang yang tidak sesuai spesifikasi oleh pemasok, pengemasan yang kurang baik sehingga terjadi kerusakan selama diperjalanan.

Maka perlu adanya upaya dalam menangani hal ini terkhusus terkait 3 faktor pengaruh terbesar. Upaya yang dapat dilakukan, dapat berupa perbaikan metode pelaksanaan, tingkat pendidikan pekerja yang lebih diperhatikan serta keahlian dari para pekerja.

\section{KESIMPULAN}

Dari data analisa dan pembahasan yang telah dilakukan maka diperoleh kesimpulan sebagai berikut:

1. Berdasarakan urutan tertinggi hingga terendah faktor pengaruh penyebab terjadinya waste Construction (Direct dan Indirect Waste) adalah Faktor Penaganan, faktor lain0lain, Faktor Pengadaan, Faktor Pelaksanaan, Faktor desain dan faktor residual.

2. Berdasarkan 3 ranking tertinggi besarnya pengaruh dari faktor faktor penyebab adalah faktor penaganan sebesar $35 \%$, Faktor 
Lain-lain 23\%, dan Faktor Pengadaan $17 \%$.

Dari penelitian ini saran yang dapat diberikan untuk penelitian selanjutnya adalah Perlu dilakukan peninjauan terhadap besarnya pengaruh terjadinya waste terhadap biaya, waktu, dan mutu secara keseluruhan, dengan memperhatikan penggunaan sumber data. Pemilihan jenis proyek bangunan gedung sebaiknya dilakukan untuk bangunan gedung yang sejenis, sehingga dapat dijadikan perbandingan dalam melihat pengaruh terjadinya waste akan menjadi lebih baik. Dalam hal ini sebaiknya informasi mengenai responden sudah diketahui dan dikonfirmasi sebelumnya, hal ini untuk mengantisipasi kekurangan data karena beberapa responden yang sulit untuk ditemui dan tidak mengembalikan kuisioner tepat waktu,

\section{DAFTAR PUSTAKA}

Alwi, S., Hampson, K., \& Mohamed, S., (2002), Waste in the Indonesian Construction Project. Proceedings of the International Conferences of CIB W107 - Creating a Sustanaible Construction Industry in Developing Countries, (hal. 305-315). South Africa.

Bossink, B. A., \& Brouwers, H. J., (1996), Construction Waste: Quantitive and Source Evaluation. Journal of Construction Engineering and Management, 55-60.

Ekanaya, L. L., \& Ofori, G., (2000), Construction material waste source evaluation. Proceedings of the Second Southern African Conference on Sustainable Development in the Built Environment. Pretoria.

Formoso, C. T., M.ASCE, L. S., Cesare, C. D., \& Isatto, E. L., (2002), Material
Waste in Building Insdutry: Main Causes and Prevention. Journal of Construction Engineering and Management.

Gavilan, R. M., \& Bernold, L. E., (1994), Source Evaluation of Solid Waste in Building Construction. Journal of Construction Engineering and Management, 536-552.

Jailoon, L., Poon, C. S., \& Chiang, Y. H., (2009), Quantifying The Waste Reduction Potential of Using Prefabrication in Building Construction in Hong Kong. Waste Management.

Kulatunga, U., Amaratunga, D., Haigh, R., \& Rameezden, R., (2006), Attitudes and Perceptions of construction workforce on Construction Waste in Sri Lanka. Management and Environmental Quality: An International Journal.

S. I., Alifen, R. S., \& L. A., (2005), Analisa dan evaluasi sisa material konstruksi: Sumber penyebab, kuantitas, dan biaya. Civil Engineering Dimension, 36-45.

Skoyles, E. F., (1976), Material Wastage. A Misuses of resources, Building Research and Practice, 232-243.

Tchobanoglous, G., Theisen, H., \& Vigil, S. A., (1993), Integrated Solid Managembet. New Jersey: McGraw-Hill. 